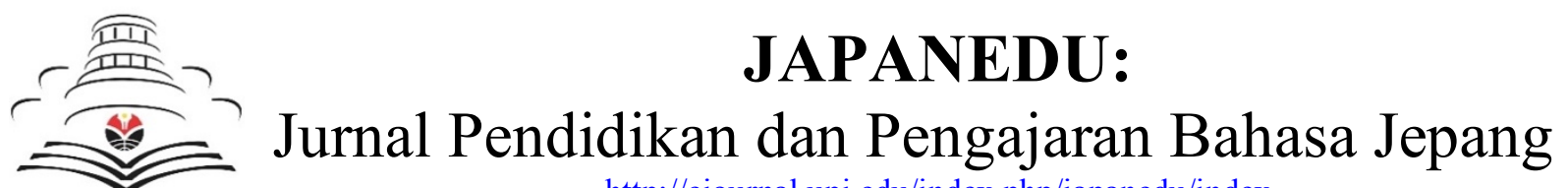

\title{
Error Analysis of Japanese Toritatejoshi Nanka, Nante, Nado and Kurai
}

\author{
Deajeng Dinda J.D.L*, Herniwati, Melia Dewi J. \\ Universitas Pendidikan Indonesia \\ *jengiiwog@gmail.com
}

\begin{abstract}
A B S T R A C T
Hyouka no toritatejoshi or known as an evaluation of toritate particle is very important in Japanese language. But there are many toritate particles with similar function and meaning, which cause some difficulties for learners to differentiate. This study aimed to analyse the error of four Japanese toritate particles namely nanka, nante, nado, and kurai, evaluating the percentage of errors, type of errors, and identify the factors that caused error in using four toritate particles. The participants of this research were 45 Japanese language students. The instruments used in this study including interview, questionnaire, and a test. The results of this study showed that the error of toritatejoshi nado which shows quotation markers in sentences was the most common type of error. While the error of toritatejoshi kurai mostly when kurai particles combined with the other toritate particles (such as $\sim$ kurainara) was the least type of error. The factors that caused errors in using those toritatejosh $i$ were mainly overgeneralization, followed by incomplete application of rules, false concept hypothesized, and the other special factors, respectively.
\end{abstract}

\begin{tabular}{c}
$\frac{\text { K E Y W O R D S }}{\text { Analysis of error; Toritatejoshi; Hyouka no toritatejoshi }}$ \\
\hline A R T I C L E I N F O \\
First received: 10 March 2020 Available online: 31 December 2020 proof accepted: 12 June 2020
\end{tabular}

\section{PENDAHULUAN}

Sudjianto dan Dahidi (2004) mengungkapkan bahwa bahasa Jepang merupakan suatu bahasa yang unik di mana bahasa ini hanya dipakai oleh bangsa Jepang sebagai bahasa nasionalnya. Jika dilihat dari aspek-aspek kebahasaan, bahasa Jepang memiliki karakteristik tertentu yang membedakan dengan bahasa lainnya. Diantaranya yaitu huruf yang dipakai, kosakata, sistem pengucapan, gramatika, ragam bahasa, dan lainlain. Karakteristik yang terdapat dalam bahasa
Jepang tersebut sering kali membingungkan dan menyulitkan pembelajar. Misalnya dalam aplikasi pemakaian kosakata, mengetahui artinya saja tidaklah cukup karena terdapat banyak kata yang apabila diterjemahkan ke dalam bahasa Indonesia memiliki arti sama, namun ternyata dalam aplikasinya memiliki struktur maupun konteks yang berbeda sehingga pemahaman mengenai pemakaian kata-kata yang memiliki kemiripan makna menjadi sangat penting. Apabila diabaikan, kemungkinan terjadinya miskomunikasi sangat besar dan dapat menimbulkan terjadinya kesalahpahaman dengan lawan tutur. 
Kesalahan dalam pemakaian tersebut salah satunya banyak terjadi pada pemakaian joshi/partikel. Menurut Matsuoka dan Takubo (1996) joshi adalah partikel yang menghubungkan klausa dengan klausa, kata dengan kata, dan yang menghubungkan kata benda sebagai kata pelengkap maupun subjek utama. Menariknya, dalam kelas kata joshi ada satu jenis partikel yang disebut dengan partikel penegas (toritatejoshi). Nitta (2009) mengartikan toritatejoshi sebagai partikel yang berfungsi menegaskan suatu unsur, melatarbelakangi hubungan antar unsur yang sama dan menambahkan makna khusus dalam suatu kalimat yang dilekatinya. Kemudian membagi partikel tersebut ke dalam 6 jenis, diantaranya yaitu ruika (penambahan), taihi (perbandingan), gentei (pembatasan), kyokugen (pembatasan sepenuhnya), hyouka (penilaian), dan bokashi (pengaburan).

Dari 6 jenis toritatejoshi tersebut, penulis tertarik untuk meneliti lebih lanjut toritatejoshi jenis hyouka yakni partikel penegas yang memiliki makna penilaian/penaksiran terhadap suatu hal. Toritatejoshi ini diantaranya terdiri dari partikel nanka, nante, nado dan kurai. Partikel penegas tersebut sering muncul dalam percakapan seharihari, dalam buku ajar maupun dalam ujian kemampuan bahasa Jepang (nouryokushiken). Berikut contoh kalimat yang menggunakan partikel penegas nanka, nante, nado dan kurai.

(1) 大丈夫大丈夫、お酒なんかで死なないよ。 Daijoubu daijoubu, osake nanka de shinanai yo. Tidak apa-apa, hanya karena sake saja tidak akan mati.

("JLPT Bunpou Kaisetsu: Nanka, Nante, Nado N2 3", 2017)

(2) 勉強なんてつまらない。

Benkyou nante tsumaranai.

Hanya belajar saja membosankan.

("Nihongo Hyougen no Fukuzatsusei ni Kansuru“, 2009)

(3) 子どもなどに負けるはずがない。 Kodomo nado ni makeru hazu ga nai. Seharusnya tidak kalah hanya pada anakanak.

("JLPT Bunpou Kaisetsu: Nanka, Nante, Nado N2 3", 2017)

(4) それをするくらい誰だってできる。

Sore wo suru kurai dare datte dekiru.

Jika hanya melakukan itu saja siapa pun bisa (melakukannya).

("JLPT Bunpou Kaisetsu: Nanka, Nante, Nado N2 3", 2017)
Kalimat (1), (2), (3) dan (4) merupakan contoh kalimat yang menggunakan partikel penegas nanka, nante,nado dan kurai. Kalimat tersebut menunjukkan suatu penilaian terhadap unsur yang ditegaskan, yakni bahwa unsur yang ditegaskan memiliki nilai yang tidak berharga, remeh dan sepele. Sehingga beberapa partikel dalam kalimat tersebut dapat saling menggantikan. Namun hasil penelitian Wawondatu (2013) dan Safitri (2017) menunjukkan bahwa pada aplikasinya, keempat partikel penegas tersebut dapat juga memiliki perbedaan makna yang beragam tergantung pada konteks dan struktur kalimatnya. Karenanya, pembelajar bahasa Jepang seringkali kebingungan dan kesulitan dalam menggunakan keempat partikel tersebut. Berikut ini adalah contoh penggunaan partikel nanka dan nante apabila disubtitusikan ke dalam kalimat (5) yang menggunakan partikel kurai.

(5) 今日くらいは家族と過ごそう。

Kyou kurai wa kazoku to sugosou.

Setidaknya hari ini habiskan waktu dengan keluarga.

(http://ejje.weblio.jp/ dalam Safitri, 2017, hal. 73)

(6) a. 今日なんかは家族と過ごそう。 Kyou nanka wa kazoku to sugosou.

Setidaknya hari ini habiskan waktu dengan keluarga.

(http://ejje.weblio.jp/ dalam Safitri, 2017, hal. 73)

b. 今日なんては家族と過ごそう。

Kyou nante wa kazoku to sugosou.

Setidaknya hari ini habiskan waktu dengan keluarga.

(http://ejje.weblio.jp/ dalam Safitri, 2017,

Pada kalimat (6), Safitri (2017) menunjukkan bahwa bagian a dan $b$ tetap berterima secara struktur, karena partikel nanka melekat pada kata kyou "hari ini" yang merupakan nomina waktu. Namun penggunaan nanka dan nante secara makna tidak berterima karena dalam ketiga partikel tersebut tidak terdapat makna yang menunjukkan makna "sedikit" atau "jumlah minimum". Sehingga dapat diketahui bahwa pada nanka dan nante tidak dapat saling menggantikan dengan partikel penegas kurai. Novitasari (2018) dan Wawondatu (2013) menunjukkan bahwa partikel penegas yang memiliki kesamaan makna seperti 
pada contoh-contoh kalimat di atas acap kali membuat pembelajar bahasa jepang kesulitan. Kesulitan tersebut menjadi salah satu faktor penyebab terjadinya kesalahan, diantaranya seperti kesalahan dalam pemahaman, salah kaprah dalam pemakaian, tertukarnya makna antar partikel, dan lain-lain. Akibatnya, menurut hasil penelitian Novianti, Rosliana, dan Rini (2016) tentang analisis kesalahan penggunaan partikel, pembelajar pun dengan mudah melakukan kesalahan pada saat ujian maupun saat menggunakannya dalam percakapan. Jika diabaikan, hal seperti ini dapat merugikan pembelajar, mengurangi efektivitas pembelajaran dan dapat menjadi kesalahan yang berkesinambungan.

Penelitian terdahulu milik Novianti, Rosliana, dan Rini (2016) menganalisis kesalahan penggunaan partikel secara umum saja. Karenanya, Penulis tertarik untuk menganalisis lebih dalam bentuk-bentuk kesalahan apa saja yang timbul dalam penggunaan partikel secara khusus, yaitu partikel penegas. Wawondatu (2013), Safitri (2017), Novitasari (2018) dan Khoirinnisa (2018) hanya membahas tiga partikel penegas yakni nanka, nante dan kurai. Dalam penelitian ini, penulis menambahkan partikel nado sehingga partikel penegas yang dibahas adalah nanka, nante, nado dan kurai. Untuk menanggulangi dan mengurangi terjadinya kesalahan berkelanjutan, penulis tertarik untuk menganalisis lebih dalam bentuk-bentuk kesalahan apa saja yang timbul dalam penggunaan partikel penegas nanka, nante, nado dan kurai serta mencari faktor penyebab terjadinya kesalahan. Kesalahan berbahasa menurut Hodri, Sadyana, dan Mardani (2019) tidak untuk dihindari, tetapi justru harus dihadapi dan diperbaiki sehingga dapat meminimalisir atau bahkan menghapuskan kesalahan yang sama supaya tidak terjadi di masa yang akan datang. Diharapkan analisis kesalahan dalam penelitian ini dapat menjadi sebuah solusi yang baik agar persentase terjadinya kesalahan dalam penggunaan partikel penegas nanka, nante, nado, dan kurai dapat berkurang.

\section{METODE PENELITIAN}

Metode yang digunakan oleh penulis dalam penelitian ini adalah metode penelitian deskriptif dengan pendekatan kualitatif. Metode ini digunakan untuk menjabarkan keadaan objek secara aktual dari kejadian aktual masa kini. Penelitian ini menggunakan data-data kuantitatif yang kemudian hasilnya di deskripsikan dengan pendekatan kualitatif.

Populasi yang digunakan penulis dalam penelitian ini adalah 45 orang mahasiswa semester VI Departemen Pendidikan Bahasa Jepang. Pemilihan populasi tersebut didasarkan atas pertimbangan bahwa mahasiswa semester VI telah mengenal dan mendapatkan pengetahuan mengenai keempat objek yang akan penulis teliti. Penentuan sampel berdasarkan pada kemampuan sampel setara N4 dan N3, juga melihat objek penelitian yang telah diajarkan kepada sampel dalam perkuliahan. Penelitian menggunakan Teknik one shoot model atau satu kali pengambilan data dengan rentang waktu 45 menit.

Instrumen yang digunakan dalam penelitian ini adalah tes berupa 25 soal jenis pilihan ganda dan 5 jenis soal jenis esai, angket berupa 13 pertanyaan, dan wawancara kepada beberapa responden. Soal yang digunakan dalam penelitian ini merupakan jitsurei (contoh soal) yang bersumber dari buku "Chuujoukyuu wo Oshieruhito no Tame no Nihongo Bunpou Handbook", "Chuukyuu Nihongo Bunpou to Oshiekata no Point", "Gendai Nihongo Bunpou 5", serta situs ydu.edu dan yourei.jp (lihat Tabel 1 dan 2). 
Tabel 1: Kisi-kisi soal tes tertulis.

\begin{tabular}{|c|c|c|c|}
\hline $\begin{array}{l}\text { Jenis } \\
\text { Toritatejoshi }\end{array}$ & \multicolumn{2}{|r|}{ Aspek } & No. Soal \\
\hline \multirow{2}{*}{ Nanka } & Makna & $\begin{array}{l}\text { Menunjukkan nilai rendah、 sepele, dan ketidakmungkinan } \\
\text { dengan bentuk negasi }\end{array}$ & $1,6,11,27$ \\
\hline & Gramatikal & Kombinasi partikel nanka dengan partikel lain & $14,16,19$ \\
\hline \multirow{3}{*}{ Nante } & \multirow{2}{*}{ Makna } & Menunjukkan penanda kutipan & $10,21,30$ \\
\hline & & Menunjukkan keterkejutan & 4,18 \\
\hline & Gramatikal & Partikel nante di akhir kalimat & 8,28 \\
\hline \multirow{3}{*}{ Nado } & \multirow{3}{*}{ Gramatikal } & Ragam kaku/formal & $2,22,17$ \\
\hline & & Nado pada kalimat penanda kutipan & 9,29 \\
\hline & & Penggunaan nado dengan bentuk V-suru & $7,13,24$ \\
\hline \multirow{3}{*}{ Kurai } & \multirow{2}{*}{ Makna } & Menyatakan batas paling rendah dan keterbatasan & $5,15,20,26$ \\
\hline & & Menunjukkan makna "sedikit" & 12,23 \\
\hline & Gramatikal & Kombinasi partikel kurai dengan partikel lain & 3,25 \\
\hline
\end{tabular}

Tabel 2: Kisi-kisi Angket.

\begin{tabular}{|l|c|}
\hline \multicolumn{1}{|c|}{ Aspek yang Diamati } & No. Soal \\
\hline Pengetahuan responden mengenai hyouka no toritatejoshi (nanka, nante, nado, kurai) & $1-5$ \\
\hline Tingkat pemahaman reponden mengenai hyouka no toritatejoshi & $6-7$ \\
\hline Kesulitan menggunakan hyouka no toritatejoshi dalam bahasa Jepang & $8-9$ \\
\hline Faktor penyebab kesulitan penggunaan hyouka no toritatejoshi dalam bahasa Jepang & $10-11$ \\
\hline Perlunya menguasai materi hyouka no toritatejoshi & 12 \\
\hline Cara mengatasi kesalahan penggunaan hyouka no toritatejoshi dalam bahasa Jepang & 13 \\
\hline
\end{tabular}

\section{HASIL DAN PEMBAHASAN}

Uji instrumen penelitian dilakukan dalam bentuk tes dan non tes. Instrumen berupa tes dilakukan dengan mengujikan 30 butir soal tentang hyouka no toritatejoshi nanka, nante, nado dan kurai. Sedangkan penelitian non test dilakukan dengan menyebar angket kepada seluruh sampel dan melakukan wawancara kepada beberapa orang sampel.

\section{Tingkat Persentase Kesalahan}

Dari identifikasi data penelitian yang telah dilakukan, dapat ditarik hasil bahwa rata-rata persentase kesalahan penggunaan hyouka notoritatejoshi nanka, nante nado dan kurai secara umum adalah sedang yakni 57,7\%. Namun jika dilihat satu persatu, dari keempat partikel penegas tersebut tingkat kesalahan tertinggi ditunjukkan pada partikel penegas nado dengan persentase kesalahan 69,25\% dan pada partikel penegas nanka dengan persentase kesalahan 61,35\%. Sedangkan pada partikel penegas nante dan kurai termasuk ke 
dalam kategori sedang yakni dengan persentase kesalahan 50,15\% (lihat Tabel 3). Dilihat dari aspeknya, secara umum persentase kesalahan tertinggi adalah pada partikel nado yang secara gramatikal menunjukkan kalimat penanda kutipan, yakni $80 \%$. Sedangkan persentase kesalahan terendah adalah pada partikel kurai yang secara gramatikal menunjukkan kombinasi dengan partikel lain, yakni 18,8\%.

Tabel 3: Persentase kesalahan total (pilihan ganda dan esai).

\begin{tabular}{|l|c|c|}
\hline \multicolumn{1}{|c|}{ Partikel Penegas } & $\mathbf{\%}$ & Tafsir \\
\hline Nanka & 61,35 & Tinggi \\
\hline Nante & 50,15 & Sedang \\
\hline Nado & 69,25 & Tinggi \\
\hline Kurai & 50,15 & Sedang \\
\hline Total & $\mathbf{5 7 , 7}$ & Sedang \\
\hline
\end{tabular}

Meskipun demikian, jika dilihat kuantitas kesalahan per tiap soal, terdapat beberapa soal dengan kesalahan melebihi $80 \%$. Berikut ini adalah pembahasan beberapa soal dengan tingkat kesalahan tertinggi dari masing-masing partikel nanka, nante, nado dan kurai.

\section{Soal 1:}

だから、僕たちは一人の恋人なんかを守り続け てはいられない。

Dakara bokutachi wa hitori no koibito nanka wo tsuzukete wa irarenai.

(Oleh karena itu, kita tidak bisa terus menerus melindungi seorang kekasih.)

Jawaban benar soal ini adalah toritatejoshi nanka karena kalimat ini memiliki makna ketidakmungkinan dalam bentuk negasi. Sedangkan partikel nante tidak dapat dilekatkan di belakang partikel kasus wo dan partikel kurai tidak digunakan dalam kalimat negasi.

Soal nomor 14 dengan frekuensi kesalahan $84,4 \%$.

\section{Soal 14:}

料理が苦手で、最も簡単なゆで卵なんかさえ作 れない。

Ryouri ga nigate de, mottomo kantan na yude tamago nanka sae tsukurenai.

(Saya tidak pandai masak, membuat telur rebus yang termudah saja tidak bisa.)
Jawaban benar soal ini adalah toritatejoshi nanka karena partikel nanka dapat dikombinasikan dengan partikel penegas lain yang menunjukkan batas (sae, demo, date). Sedangkan partikel nante dan kurai tidak dapat dikombinasikan dengan partikel yang menunjukkan batas seperti nanka.

Soal nomor 27 (esai) dengan frekuensi kesalahan $60 \%$.

\section{Soal 27:}

旅行なんかに行っている暇はない。 Ryokou nanka ni itteiru hima wa nai (Saya tidak punya waktu luang untuk pergi berlibur.)

Jawaban benar soal ini adalah toritatejoshi nanka karena pada soal ini nanka menunjukkan penilaian bahwa unsur yang ditegaskan memiliki nilai yang rendah atau tidak berharga. Sedangkan partikel nante tidak dapat diletakkan di depan partikel kasus ni, nado tidak tepat digunakan pada kalimat informal dan kurai tidak dapat digunakan dalam kalimat negasi.

Pada partikel nante soal dengan kesalahan tertinggi terdapat pada soal nomor 10, 21, dan 30 .

Soal nomor 10 dengan frekuensi kesalahan $53,3 \%$.

\section{Soal 10:}

いったい、一人一人の役人が許すなんていうこ とをできるものだろうか。

Ittai, hitori hitori no yakunin ga yurusu nante iu koto wo dekiru mono darouka.

(Dapatkah Anda mengatakan bahwa setiap pejabat akan memaafkan?)

Jawaban benar soal ini adalah toritatejoshi nante karena dalam kalimat ini nante memiliki makna yang sama dengan nadoto atau nadotoiu dengan cara melesapkan partikel to yang mengikutinya. Sedangkan partikel nanka tidak memiliki fungsi sebagai penanda kutipan dan nado perlu melekatkan partikel kasus to untuk menunjukkan penanda kutipan.

Soal nomor 21 dengan frekuensi kesalahan $64,4 \%$.

\section{Soal 21:}

私が責任を負うなんてことになってしまった。 Watashi wa sekinin wo ou nante koto ni natte shimatta. (Saya jadi harus bertanggung jawab) 
Jawaban benar soal ini adalah toritatejoshi nante karena dalam kalimat ini nante memiliki makna yang sama dengan nadoto atau nadotoiu dengan cara melesapkan partikel to yang mengikutinya. Sedangkan partikel nanka tidak memiliki fungsi penanda kutipan dan nado perlu melekatkan partikel to untuk menunjukkan penanda kutipan.

Soal nomor 30 (esai) dengan frekuensi kesalahan $82,2 \%$.

\section{Soal 30:}

田中さんは友達と二人でお弁当屋をやってるん だけど、店では社長なんてよばれていたわよ。

Tanaka-san wa tomodachi to futari de obentouya wo yatterundakedo, mise de wa shachou nante yobareteita wayo.

(Tanaka-san membuka toko bento berdua dengan temannya, namun ketika di toko dipanggil sebagai kepala toko.)

Jawaban benar soal ini adalah toritatejoshi nante karena dalam kalimat ini nante memiliki makna yang sama dengan nadoto atau nadotoiu dengan cara melesapkan partikel to yang mengikutinya. Sedangkan partikel nanka dan kurai tidak memiliki fungsi sebagai penanda kutipan dan nado perlu melekatkan partikel kasus to untuk menunjukkan penanda kutipan.

Pada partikel nado soal dengan kesalahan tertinggi terdapat pada soal nomor 13, 17 dan 29. Soal nomor 13 dengan frekuensi kesalahan $66,7 \%$.

\section{Soal 13:}

このような場所があるなど信じられません。 Kono youna basho ga aru nado shinjiraremasen. (Saya tidak percaya ada tempat seperti ini.)

Jawaban benar soal ini adalah toritatejoshi nado karena partikel nado dapat dilekatkan dengan verba bentuk kamus. Sedangkan partikel nanka tidak dapat dilekatkan dengan verba bentuk kamus dan kurai tidak dapat digunakan pada kalimat negasi. $75,6 \%$.

Soal nomor 17 dengan frekuensi kesalahan

\section{Soal 17:}

委員会の代表など、私にはとうてい務まりませ 几。

Iinkai no daihyou nado, watashi ni watoutei tsutomarimasen.

(Saya tidak akan bekerja untuk perwakilan komite.)
Jawaban benar soal ini adalah toritatejoshi nado karena partikel nado lebih tepat digunakan dalam situasi formal/kaku dan tidak tepat jika digunakan pada situasi informal. Sedangkan nanka kurang tepat digunakan karena situasi kalimat diatas adalah formal/kaku dan kurai tidak dapat digunakan dalam kalimat bentuk negasi.

Soal nomor 29 (esai) dengan frekuensi kesalahan $80 \%$.

\section{Soal 29:}

父の言うことはすべてただしいなどと思いませ ん。

Chich i no iu koto wa subete tadashii nado to omoimasen. (Saya tidak berpikir semua yang dikatakan ayah saya benar.)

Jawaban benar soal ini adalah toritatejoshi nado karena nado dapat digunakan untuk menunjukkan penanda kutipan dengan merubah strukturnya menjadi nadoto diikuti iu/omou. Sedangkan pada partikel nanka dan kurai tidak terdapat fungsi sebagai penanda kutipan dalam kalimat dan pada partikel nante partikel kasus to harus dilesapkan ketika digunakan sebagai penanda kutipan dalam kalimat.

Pada partikel kurai soal dengan kesalahan tertinggi terdapat pada soal nomor 5, 23 dan 26.

Soal nomor 5 dengan frekuensi kesalahan $55,6 \%$.

\section{Soal 5:}

この難しい仕事をやりとげられる人は、鈴木さ んくらいだと思う。

Kono muzukashii shigoto wo yaritogerareru hito wa, Suzuki-san kurai da to omou.

(Saya pikir yang dapat mengerjakan pekerjaan sulit ini, hanyalah Suzuki-san seorang.)

Jawaban benar soal ini adalah toritatejoshi kurai karena partikel kurai dapat digunakan untuk menyatakan suatu keterbatasan, bahwa hanya unsur yang ditegaskanlah yang dapat diterapkan, tidak ada yang lain. Sedangkan apabila disempurnakan dengan partikel nanka atau nado kalimat tersebut jadi bermakna rancu.

Soal nomor 23 dengan frekuensi kesalahan $40 \%$.

\section{Soal 23:}

この料理の作り方は秘密だそうだが、少しくら い教えてほしい。 
Kono ryouri no tsukuri kata wa himitsu da souda ga, sukoshi kurai oshiete hoshii.

(Meskipun sepertinya cara membuat masakan ini rahasia, tapi beritahukan lah sedikit.)

Jawaban benar soal ini adalah toritatejoshi kurai karena partikel kurai yang menegaskan unsur kuantitas dapat digunakan untuk mengungkapkan penilaian bahawa unsur tersebut bernilai sedikit. Sedangkan apabila disempurnakan dengan partikel nanka atau nante karena keduanya tidak dapat digunakan untuk menegaskan unsur kuantitas dan tidak memiliki makna sedikit, kalimat tersebut jadi bermakna rancu.

Soal nomor 26 (esai) dengan frekuensi kesalahan $68,9 \%$.

\section{Soal 26:}

息子にはせめて高校くらいは卒業してほしい。 Musuko ni wa semete koukou kurai wa sotsugyou shite hoshii.

(Saya ingin anak laki-laki saya lulus setidaknya di SMA.)

Jawaban benar soal ini adalah toritatejoshi kurai karena partikel kurai yang menunjukan suatu perbandingan dikombinasikan dengan partikel wa dan nara menjadi kurainara, kuraiwa dan dapat pula menjadi semete kuraiwa. Sedangkan partikel nanka, nante, dan nado tidak dikombinasikan dengan semete wa dan secara makna tidak pula menunjukan suatu batas minimum.

\section{Jenis-Jenis Kesalahan yang Muncul}

Jenis-jenis kesalahan yang muncul dari jawaban rrsponden di antaranya adalah, (a) kesalahan dalam membedakan kalimat penanda kutipan nado dan nante terhadap partikel to yang mengikutinya, (b) penyamarataan kaidah bahwa nanka,nado dan kurai dapat diberlakukan pada struktur kalimat nante yang dapat diletakkan di akhir kalimat sebagai pernyataan keterkejutan, (c) melekatkan partikel nanka pada verba bentuk kamus, (d) melekatkan partikel kasus ni, to dan wo di belakang partikel kurai dan nante, (e) penyamarataan partikel nanka dan nante dengan partikel nado dalam kalimat berbentuk baku/formal, (f) mengaplikasikan partikel kurai pada kalimat bentuk negasi, (g) mengkombinasikan partikel penegas nante dengan partikel penegas lain.

\section{Faktor Penyebab Kesalahan}

Faktor penyebab kesalahan penggunaan partikel penegas nanka, nante, nado dan kurai terdiri atas dua faktor, yakni faktor umum dan faktor khusus.

Faktor umum penyebab kesalahan antara lain sebagai berikut.

1. Overgeneralization, penyebabnya adalah perluasan kaidah pada struktur partikel penegas nanka, nante, nado dan kurai yang kurang tepat. Responden melakukan penyamarataan struktur kalimat pada beberapa partikel penegas dikarenakan bentuk/struktur kalimat dan subjek yang ditegaskan memiliki kemiripan. Contohnya seperti pada struktur kalimat nante dan nanka yang disamaratakan dengan bentuk formal/baku partikel nado.

2. Incomplete application of rules, penyebabnya adalah penyimpangan struktur karena penerapan kaidah tata bahasa pada hyouka no toritatejoshi yang tidak sempurna. Responden menambahkan dan menghilangkan partikel kasus yang seharusnya melekat pada partikel penegas tersebut, kombinasi hyouka no toritatejoshi dengan partikel lain tidak sesuai dengan aturan yang ada, penyimpangan struktur karena partikel nanka dilekatkan pada bentuk verba yang tidak seharusnya, meletakkan partikel kurai, nanka, dan nado pada posisi yang tidak tepat, dll.

3. False concept hypothesized, penyebabnya adalah perumusan kaidah secara keliru, kesalah pahaman bahwa kaidah pada partikel yang satu dapat diberlakukan pada struktur partikel yang lain. Responden salah menghipotesiskan bahwa bahwa suatu partikel dapat dikombinasikan dengan partikel penegas lain seperti hyouka no toritatejoshi lainnya. Salah kaprah bahwa struktur penanda kutipan pada suatu partikel penegas dapat diberlakukan juga pada struktur penanda kutipan partikel penegas lain.

Selain faktor umum, terdapat pula faktor khusus yang berkaitan dengan proses dan kegiatan pembelajaran bahasa seperti berikut ini.

1. Strategi pembelajaran B2 yang salah, diantaranya adalah terlalu terpakunya responden terhadap materi yang diberikan di perkuliahan menyebabkan sempitnya sumber ilmu pengetahuan, banyaknya responden yang tidak mempelajari kembali teori yang telah diberikan dosen di perkuliahan menyebabkan kelupaan berkala. 
2. Transfer of training, diantaranya adalah beberapa hyouka no toritatejoshi hanya diajarkan sepintas di mata kuliah lain bukan pada mata kuliah tata bahasa (bunpou), kebanyakan responden hanya diberitahukan mengenai persamaan antar toritatejoshi tanpa disertai dengan perbedaanya, kurang spesifiknya pengajaran mengenai hyouka no toritatejoshi di perkuliahan.

3. Strategi komunikasi, diantaranya adalah kurangnya intensitas kemunculan dan pemakaian hyouka no toritatejoshi pada responden, kurangnya kesempatan yang didapatkan responden untuk menggunakan masing-masing partikel yang telah dipelajarinya.

\section{KESIMPULAN}

Berdasarkan hasil penelitian dapat disimpulkan bahwa tingkat persentase kesalahan penggunaan hyouka no toritatejoshi nanka, nante, nado dan kurai secara umum adalah 57,7\% dengan tafsiran sedang. Sedangkan, Persentase kesalahan masingmasing partikel penegas diantaranya adalah nanka $61,35 \%$, nado $69,25 \%$, nante dan kurai $50,15 \%$. Kesalahan penggunaan yang muncul disebabkan oleh adanya faktor-faktor seperti kurangnya pemahaman responden terhadap kaidah struktur dan penggunaan toritatejoshi nanka, nante, nado dan kurai. Hal itu diakibatkan oleh strategi belajar rsponden yang terlalu terpaku terhadap materi yang diberikan, sementara pengajaran mengenai toritatejoshi sendiri kurang spesifik diberikan di perkuliahan.

Analisis kesalahan terhadap penggunaan toritatejoshi selain nanka, nante, nado dan kurai perlu dilakukan untuk meminimalisir persentase terjadinya kesalahan yang dilakukan pembelajar dalam penggunaan partikel penegas dalam bahasa Jepang.

\section{REFERENSI}

Hodri, M., Sadyana, I. W., \& Mardani, N. M. D. S. (2019). Analisis kesalahan penggunaan partikel pada mata kuliah sakubun shochuukyuu mahasiswa semester 3 program studi pendidikan bahasa jepang undiksha tahun ajaran 2017/2018. JPBJ, 5(1), 45-54. Diakses dari https://ejournal.undiksha.ac.id/index.php/JJPBJ/ article/download/17035/13711

JLPT Bunpou Kaisetsu: Nanka, Nante, Nado N2 3. (2017). Diakses dari https://jn1et.com/nanka-nante-nado/

Khoirinnisa, U. (2018). Partikel penegas bakari hodo dan kurai dalam kalimat bahasa Jepang (Skripsi, Universitas Diponegoro Semarang). Diakses dari http://eprints.undip.ac.id/67995/

Matsuoka, T., \& Takubo, Y. (1996). Kiso Nihongo Bunpou. Tokyo: Kuroshio Publishing.

Nihongo Hyougen no Fukuzatsusei ni Kansuru. (2009). Diakses dari ir.ydu.edu.tw/ uchiyama/conv/nante.html

Nitta, Y. (2009). Gendai Nihongo Bunpou 5. Tokyo: Kuroshio Publishing.

Novianti, D., Rosliana, L., \& Rini, E. (2016). Analisis kesalahan penggunaan partikel $d e$, ni, dan o pada kalimat pembelajar bahasa jepang. Jurnal Japanese Literature, 2(2), 1-8. Diakses dari https://ejournal3.undip.ac.id/index.php/japliterat ure/article/download/12532/12162

Novitasari, R. (2017). Toritatejoshi ' $m o$ ' sebagai partikel penegas dalam kalimat bahasa jepang. Jurnal Ayumu, $4(2)$,

110-133. https://dx.doi.org/10.25139/ayumi.v5i2.386

Safitri, M. (2017). Partikel penegas nanka, nante dan kurai dalam kalimat bahasa Jepang (Skripsi, Universitas Diponegoro Semarang). Diakses dari http://eprints.undip.ac.id/56443/

Sudjianto, S., \& Dahidi, A. (2004). Pengantar Linguistik Bahasa Jepang. Jakarta: Kesaint Blanc Publishing.

Wawodatu, Y. (2013). Penggunaan partikel nanka dan nante dalam komik Hanazakarino Kimitachi e karya Nakajou Hisaya. Humanis, 5(3), 1-8. Diakses dari https://ojs.unud.ac.id/index.php/sastra/article/vie $\underline{\mathrm{w} / 7151}$ 